\title{
Influence of COVID-19 Transmission on the Increase or Decline of Government Role from the Perspective of Realists and Liberators
}

\author{
Ali Asghar Modaber \\ Assistant Professor, Lecturer at Faculty of Law and Political Science - Herat University - Herat Province - Afghanistan
}

\begin{abstract}
The right of health is one of the most fundamental human rights, which is emphasized in human rights documents. The spread of the corona virus has posed major challenges to the various dimensions of human rights, the most important of which is the right of being health. There are basically two perspectives about the belief in the role of government and international law in general. The first view is the realists view, who see the behavior of governments based on their benefits the and question the implementation of international law. The second group is the liberals, who place great emphasis on the application of international law. According to the beliefs of this group, governments also generally have certain responsibilities in relation to securing and guaranteeing this right. It is clear that governments cannot fully guarantee the health and well-being of individuals, but governments can provide conditions in which the health of individuals is protected and access to health is possible for individuals. This obligation is driven from the obligations of governments to implement human rights in accordance with international law.
\end{abstract}

Keywords: corona, government, international low, liberates, realists

\section{Introduction}

The coronavirus (Corona Virus Disease 2019 (COVID-19)) first spread in Wuhan, China in December 2019, and due to its rapid and deadly prevalence, it was in the center of the international community's attention, and of course its international legal issues, especially from a human rights perspective, are controversial. The World Health Organization is publishing daily reports about the prevalence and spread of the virus in the world, and due to the considerable access of people around the world to cyberspace, news and related information are rapidly available to the public. However, not only there is still no consensus on the origin of the virus, its relationship to SARS and other previously contagious diseases, but there are serious ambiguities about how international health regulations should beused and its workability against corona. Can international law governing this world, oblige governments to comply with international health regulations? Does international law have the power to oblige states to impose restrictions or prohibitions on the entry and exit of individuals within the territory of their national borders, or even to impose restrictive trade measures? While liberals believe that with the advent of a virus like Corona, the role of international law has become more colorful and the power of government has been declining, realists believe that, on the contrary, the role of government in the fight against Corona has been constructive. Ultimately, the truth has been that the coronavirus phenomenon has been a common ground that reconciles the two approaches.

\section{Research question}

Specifically, the question of this research is "What effect has the outbreak of the Corona virus had on the application of international law at the domestic level of countries according to the theory of realism and liberalism?"

\section{Research hypothesis}

The hypothesis considered in this article is as follows:
"Realists believe that the outbreak of the coronavirus has increased the role of governments in domestic affairs and further weakness of international law, but liberals, on the other hand, believe that the outbreak has led to the application of international law inside the countries and Governments role is declining."

\section{Research Methods}

The method used in this paper is analytical-comparative, which compares two broad theoretical foundations in the international area regarding a new issue that has started from the field of accuracy and has affected other fields based on comparisons. It is conceivable that the method of collecting research is library.

\section{The importance of research}

In the classical international community, first of all, war and peace were considered as the only points of intersection and communication between states in the international area, but today there are very wide and diverse issues in this field. One of these issues, which has been discussed for almost a year, is corona disease, which countries around the world are dealing with. On the other hand, the issue of globalization and the authority of supranational institutions has long been the cause of various intellectual fronts at the international level. Among these fronts, realists and liberals have expressed detailed issues and different arguments. In this article, in addition to stating the main assumptions of each of the above approaches, their perspective on increasing or decreasing the scope of government or international institutions in the world after the corona outbreak is discussed. Therefore, the importance of this article in expressing various views and the method of their reasoning is also evident, as well as how two multiple interpretations of an issue can be made and how each of the above approaches uses a subject to the benefits of their assumptions. 


\section{Research purposes}

- Familiarity with fundamental international approaches (liberalism and realism)

- Understanding of the reasoning of different approaches to the major issue of 2020

- Recognize some of the changes caused by corona disease internationally

\section{Basic principles of realism}

Realism, which is translated as realist, is based on four assumptions: 1) a pessimistic view of human nature; 2) War is the ultimate solution to resolving international disputes; 3 ) National security and the survival of the government are the highest values; 4) Pessimism about international politics can progress like domestic political life (Jackson and Sorenson, 2012: 93).

For realists, the main and determining criterion in international relations is power. Success is for those governments that have the most power and use it as the best. According to realists, governments are the main actors in the contemporary world and have the most power. Governments control most of the world's military and armed forces, and they are also the only unit that can collect taxes from those who are under their control. International organizations do not have this feature. From the realists' point of view, international organizations reflect the existence of benefits and the balance of power among powerful governments. Therefore, these organizations are not considered as independent actors and play a more instrumental role in the war between governments (Barkin, 2014: 19-20).

Governments must pursue their national interests. That is, states and governments never fully trust each other. All international agreements are temporary and subject to the willing of the signatory governments, and all governments must be prepared to sacrifice international obligations if they conflict with their national benefits. Therefore, all treaties, agreements, conventions, customs, laws and rights between governments are only expedient arrangements and in case of conflict between them with the vital benefits of states, they should be abandoned. According to realists, organizations and institutions can be effective or can encourage governments to cooperate when it is the benefit of a governments to do so. But the risk of free rides or their relative benefits prevents them from expanding cooperation in the form of international institutions.

Realists believe that extreme insecurity does not allow human moral considerations to take precedence over the core national considerations of governments, and that it is these benefits that determine political action, and that politics on the world stage is an immoral struggle for power to advance these benefits. 1392: 92).

Although realism is a broad-based approach that incorporates a variety of theories, it has, as stated, general principles that include emphasizing governments and their benefits, discussing power, and rejecting morality as an internal driver of action, especially at the international level. In the following, we will analyze this approach of the new global phenomenon "Corona".

\section{Corona Prevalence and Realists Analysis}

Realists in their predecessors 'writings had analyzes the infectious diseases, such as Thucydides' writings in Peloponnesian Wars. In these wars, Athens was plagued by the plague for three years in $430 \mathrm{BC}$. Historians believe that at that time the plague killed about a third of the Athenian population, including prominent leaders such as Proclus, and had a very negative effect on Athens' long-term power. Today, the United States continues to be a major player in world politics. Therefore, if the corona trend continues, US thinkers and researchers will see the United States a weak one in global affairs and other areas of society.

According to this theory, when a new danger appears, human beings primarily look inside their borders to be safe from this danger. For example, after 9/11, the United States did not turn to the United Nations or Amnesty International for litigation, but turned to Washington and its federal government. Even today, citizens around the world look at their country's officials for decisive action and appropriate accountability. "There is no libertarianism in the epidemic," said journalist Drake Thompson. As a result, unlike a world government, governments are still central politics players in today's world. Realists have been emphasizing this point for decades, and the spread of the coronavirus is an emphasis on this thinking.

Realists in general do not view globalization in a positive light, especially recently, believing that other close ties between governments in trade, investment, travel, transportation, the digital revolution, or even democratization will not expand. The reason for this is the negative dimensions of globalization. People will be more cautious in establishing cross-border relations. As Kenneth Waltz wrote in his Theory of International Politics: Domestic necessity is specialized, and international necessity is self-care. Another realist, Rain Hold Niebuhr, predicted such a danger in the 1930s. He wrote that the expansion of international trade, the expanding economic interdependence between nations, and all the civilized technological apparatus increase the problems of nations between their ability to solve them.

Criticisms of the theory of liberalism and the expansion of interdependence between governments believe that close relations can be a source of vulnerability and potentially cause conflict. What Waltz and Niebuhr say is that close relations between governments will exacerbate their problems beyond what they can solve. Sometimes these problems are faster than the solution can be found. To this end, governments (the main player in international politics) are trying to reduce risk and vulnerability by restricting relations with each other. Thus, from the perspective of coronavirus realism, it became another reason for governments to limit globalization. The globalization of the international financial system has made it more vulnerable to crises and has created numerous domestic political problems. According to Stephen Walt, coronary heart disease will affect globalization. He believes that globalization will not stop, but after this global crisis, governments will impose more restrictions on their borders (Walt, March 9, 2020, Foreign policy.com). 
As a result, national governments will strengthen their role in domestic and international politics during the war on virus. These actors impose restrictions on movement, increase the decision-making role in carrying out their responsibilities to the people who have elected them, invest in their internal capacity, and reduce their degree of dependence on the global chain, belief in global values, and They are protesting against the global multinational community and have always understood politics from a moral perspective from within the country and the internal security of the country (Tarı Oğuzlu, 20/3/2020, Dailysabah.com).

There are two major criticisms of realism: First, the tradition has a very limited view and usually deals with military and power issues. Second, the global problem of the people should be considered regardless of whether the citizens are the creators of the government, and international issues are no longer limited to national security and defense, and other phenomena should also be considered (Jackson and Sorenson, 2012: 136). Security issues are not always military, but issues such as health can also jeopardize a country's security. Thus, the realists' limited view of security (which also places the greatest emphasis on military affairs) has led to widespread criticism of this approach. Ignorance of international law in the conduct of states also raises another important criticism of this approach. There have been other criticisms of this approach, some of which address the issue of liberalism.

\section{Liberalism}

The tradition of liberalism is rooted in the study of international law and is the most important approach to its creation and development. Liberalism has many branches, including internationalists and institutionalists, who are more closely associated with international law. The tradition of internationalism views governments in the international community as individuals in domestic societies. The life of internal communities is usually sustained by the observance of the law by the majority of individuals. From the internationalists' point of view, there are accepted rules about how governments communicate, and we cannot understand international politics without considering these rules. Even in times of war, when the international community is expected to be at its weakest, governments often look for acceptable rules of communication. Governments believe that a society in which law and order prevails is beneficial to all and therefore tends to accept rules for the rule of law, provided that other states are also committed to enforcing these rules. Accordingly, international organizations, as international actors, have specific and distinct effects on international relations, and the extent of these effects depends on two factors: whether international organizations themselves establish rules and norms or merely oversee rules that in turn It stems from agreements. But in any case, international organizations are very important because they regulate relations between governments (Barkin, 1393: 20).

According to liberal internationalists, globalization is eroding domestic sovereignty. As the international community has grown stronger, governments have increasingly tended to create collective rules. In international trade, for example, there are so many rules that if it did not exist, governments would be extremely vulnerable. The internationalist tradition also believes that globalization has not yet led to the weakening of the sovereign system of states. In this sense, it is true that international rules are adopted collectively by a group of states, but it should be noted that these groups are made up of states.

The growing tendency of states to create collective rules is called "multilateralism", which is the basis of internationalist analysis. Governments often act individually in unilateralism, and in bilateralism two governments act together. Multilateralism refers to a system in which governments are expected to act as a group and through negotiation within international organizations. Multilateralists believe that governments still sometimes act alone, but this has become an exception to government behavior. Only governments have the right to vote in international organizations and should participate in international policy-making. In other words, the multilateral system seeks to create a new type of government instead of weakening it (Barkin, 2014: 21-22).

Liberals today (with less optimism than classical liberals) believe that transnational institutions can lead to better and more cooperation. International institutions are not just in the service of powerful governments. They have a lot of independence and can cause cooperation between governments (Jackson, 2012: 155).

Liberals acknowledge that intergovernmental cooperation is limited and limited, especially where it involves profit. But in an environment of growing global and regional convergence, governments can often, with or without the encouragement of a hegemon, reconcile economic and strategic interests that can be formally agreed upon and set rules of conduct. The argument for formal cooperation between governments in areas such as environmental degradation and the threat of terrorism are interesting (Barchil et al., 2013: 88). In the case of Corona, it is said that although the United States did not take it seriously at first and did not take steps to quarantine or reduce various exchanges, other countries did so. This cooperation went so far as to call into question the actions of the United States, and the further spread of the virus caused the United States, in addition to adhering to health rules, to suffer heavy casualties. This was evident in the recent US election and the victory of the Democratic Party. Showed on the Republican. Thus, contrary to the view of the realists that powerful and hegemonic countries have the greatest influence on international affairs, contrary to the direction of the United States, other countries and international organizations, including the World Health Organization, established rules of conduct and eventually forced the United States to do so.

Liberals believe that the legitimacy of domestic political order depends largely on supporting the rule of law and respect for the human rights of citizens. The creation of important statutes, documents and legal institutions in the post-World War II era is the measure of success in this field. The most important documents are the Universal 
Declaration of Human Rights (1948), the International Covenant on Political and Civil Rights (1966) and the International Covenant on Economic, Social and Cultural Rights (1966) (Barchil, 1392: 90).

One of the criticisms of liberalism is its emphasis on the expansion of the global political economy, which promotes human peace and prosperity. In particular, the role of governments in social and economic affairs must be reduced. But the emergence of unexpected factors such as terrorism and now epidemics such as coronation has challenged these liberal assumptions. Today, society first looks to the government to protect people from disasters such as terrorism or disease. Everyone expects governments to deal with such problems. On the other hand, we must pay attention to the influence of international law and international institutions within countries, in which liberalism has a great hand. In the following, according to the view of liberalism, the impact of the spread of coronary heart disease on the application of international law is examined in more detail.

Reflection of liberals' assumptions in the rules of international law (especially in the field of correctness) in the domestic rules of countries

The health of the soul and the right to a healthy life are inalienable rights of citizenship, as one of the main characteristics of an ideal society is to have a state of good health. In this area, we must pay attention to the responsibility of the government in providing public health and meeting the needs of the nation's therapists in accordance with the Covenant of the Nation and the Government (Constitution) and the international agreements and commitments of the government against international organizations. It should also be noted that the acceptance of government responsibility is one of the most important challenges in the field of human rights, which indicates the passage of the era of absolute government immunity and the acceptance of civil responsibility for governments in the international and domestic system. The following examines the responsibility of the government against the people in accordance with the teachings of human rights and then the international responsibility of states, in the creation of which the services of liberal thinking and reasoning cannot be ignored.

\section{The responsibility of governments against the people}

The philosophy of the government is to provide services to the citizens of the country and to prepare appropriate strategies to help them. The government should help the people in all cases by having effective executive facilities, information system, police force and executive organs, cooperatives and insurance organizations, and the possibility of forming compulsory insurances and allocating funds to help people in compensating for losses (Hosseini, 2015: 129). Ensuring physical and mental health is a major part of the role of governments, which, while addressing the sociological environment of the people, requires addressing the important point that people should not worry about paying for illness. Fear of getting sick, worrying about financing one's own treatment is a social disease that endangers people's work efficiency and social status (Aghababaian, March 15, 2017, Khabaronline.ir).
Governments are the main obligors of the right to health. The possibility of such obligations is possible for them, meaning that governments can only fulfill various instances of the obligation of health, including: commitment to respect, commitment to support and commitment to performance.

- Commitment to respect for the right to health means that governments do not impose barriers or restrictions on individuals or groups of individuals in exercising this right, or that they remove existing barriers and current restrictions. In its description, the Committee on Economic, Social and Cultural Rights listed these examples as a commitment to respect for the right to health; Commitment to refrain from restricting or restricting equal access to all preventive, medical and palliative care services related to health, to avoid depriving or restricting the access of groups such as prisoners, detainees, minorities and immigrants, etc. to health services, to avoid Implement discriminatory practices related to women's health status and needs, avoidance of prohibitions or obstruction for preventive care, commitment to refrain from distributing unhealthy drugs, etc. Related issues.

- Commitment to protection also refers to the commitment of governments to safeguard and protect the right to health in the face of aggression and violation of this right by government bodies or institutions or private individuals. This dimension involves avoiding the violation of the right and preventing others from violating it. In this regard, the following issues have been stated; Commitment of governments to enact laws and regulations or to take measures to ensure equal access to health care and related services; Commitment and assurance that health sector privatization does not pose a threat to the availability and quality of access to health facilities and services; Commitment to control And monitoring the market of medical equipment, pharmaceuticals, etc., prohibiting third parties from forcing women to impose traditional procedures, and other Issues.

- Commitment to the right to be health also means taking the necessary steps to meet people's health needs. Governments are obliged to provide the necessary facilities of the right of being health (Aghababayan, March 15, 2017, Khabaronline.ir).

Therefore, the government has a civil responsibility to protect the health of people in society. Civil liability means responsibility for duties and is of two types, contractual civil liability and non-contractual civil liability, the second type of which are called non-contractual civil liability, noncontractual civil liability, special civil liability, coercive guarantee, liability. Fault, non-contractual civil liability and non-contractual civil liability are also mentioned. Therefore, when someone is harmed by doing or not doing another act, the one who made a damage, is obliged to compensate the damage done to the victim. The word "other" in this sentence means to include any harmful person, this harmful person can be a natural or legal person, and the government is included in the category of legal persons. On the one hand, in accordance with Article 52 of the Afghan Constitution, "the government shall provide free medical 
care and facilities for all citizens in accordance with the provisions of the law." On the other hand, Article 51 of the Afghan Constitution states that "any person who is harmed by the administration without cause shall be entitled to compensation and may file a lawsuit in court to obtain it." Article 776 of the Civil Code of Afghanistan states: If the government inflicts damage on another person, it shall state that if it causes damage to another person due to an error or fault, "Compensation is required." Another Article 779 of the Civil Code of Afghanistan states: "The court shall determine the compensation in proportion to the loss of income, provided that the said damage originated directly from the harmful act." Therefore, there must be a loss, a harmful action and a causal relationship between the damage and the harmful action.

If citizens of the country are infected with the corona virus due to mismanagement, bad management, negligence, late action or other similar government titles, such as the government not closing its borders, restrictions Has not established entry and exit borders, does not have sufficient diagnostic packages and health personnel at the land borders and airfields, and because of this, the virus enters the territory of the country, and as a result of the virus, the citizens of the country become infected and lose their lives. Or for the aforementioned reasons on how the virus enters the country, quarantine regulations, restrictions on travel and closure of work and private cargo are imposed on the country, the people of the nation suffer psychological, human and financial losses, it is said that the government should compensate these people. But since this kind of loss is not universal and limited to a few individuals, but the whole country suffers from it, and this is far from the financial ability and time of the courts when handling the case of each person of a country and Estimate the fines imposed on him and order its compensation, so it seems that the possible way is for the government to use different compensatory methods, depending on the case, using experts and expertise. (Mohammadyar 25 Hamal 1399: dailyafghanistan.com) and provide the necessary health facilities to the people.

Therefore, according to liberals, governments are obliged to respect and protect the health rights of their citizens. They have this obligation to their citizens, which was stated in this section. In the following, we discuss the international responsibility of governments to respect these rights.

\section{International responsibility of governments}

The main goal of governments established by the United Nations (World Health Organization and the Human Rights Council) is to bring all people across the globe to a level of health where they can enjoy a good social and economic life. The inclusion of health as an integrated part of economic and social development has become a major tool for socioeconomic development and the creation of a new social order (Aghababaian, March 15, 2017).

According to the definition of the World Health Organization, health is a state of complete physical, mental and social well-being and does not refer only to the absence of disease or disability. Human health is essential for achieving peace and security, which depends on the highest level of cooperation between people and governments (Rahimi, 1389: 54).

The right to health, which is a right related to the right to life enshrined in Article 6 of the International Covenant on Civil and Political Rights, is recognized in paragraph 1 of Article 25 of the 1948 Universal Declaration of Human Rights and in Article 12 of the International Covenant on Economic, Social and Cultural Rights (1966). ) Has been specified, which is investigated below.

- About the restriction of traffic, Article 12 of the International Covenant on Civil and Political Rights states that "everyone has the right to leave any country, including his own.This right has no limitation, except the limitations which is determined by the low and it shall provide for the maintenance of national security, public order, health or public morality, or the rights and freedoms of others, and shall be consistent with the other rights recognized in this Covenant." Article 21 of the Covenant also states: "The right to form a peaceful assembly shall be recognized. This right has no limitation, except what is determined according to the low, about the protection of public health or morals or the rights and freedoms of others which is necessary."

- Article 12 of the International Covenant on Economic, Social and Cultural Rights of 1966 states: 1. ensuring the full realization of this right will include the necessary measures to ensure the following: prevention and treatment of epidemic-endemic occupational and other diseases, as well as the fight against these diseases, the providing the appropriate condition and the of emergency actionsfor physicians when people "Get sick."

- The universal Declaration of Human Rights Article 25 "Everyone has the right to a standard of living adequate for the health and well-being of himself and his family, in particular as regards food, clothing, housing, medical care and basic social services." "In case of unemployment, illness, disability, widowhood, aging or in all other cases, who has lost his livelihood for reasons beyond his control, he should benefit from social security."

In addition to liberals' emphasis on human rights concepts, this approach has a particular bearing on international organizations. In particular, in order to ensure the health of communities and individuals, various organizations have been established at the international level, the most important of which is the World Health Organization (WHO). It is one of the United Nations agencies whose main goal is to coordinate and promote the state of public health worldwide. In addition to having the members of the general assembly, the executive board and the secretariat, it has regional institutions in six regions of the world (Eastern Mediterranean, Africa, Europe, Western Pacific, Southeast Asia and the United States) and has offices in most capitals of the world (Musazadeh, 1388: 238).

In addition to health-oriented issues, the World Health Organization has implemented extensive programs on various diseases such as tuberculosis, malaria, chickenpox, leprosy, Ebola, AIDS and Corona (Rahimi, 2010: 56). It is noteworthy that since 2007 (13 years) 6 viruses that were in 
different areas have been urgently on the agenda of this organization, the last of which is Corona. In the case of the corona virus, the organization took different steps and had one of the most important plans in the world to deal with the virus. The organization released its first report on January 21,2020 , announcing the virus in four countries. So far, more than 40 reports of the virus have been reported.

One of the most important functions of the World Health Organization (WHO) was to establish the International Health Organization (IHR) in 2005, under which governments agreed to increase their discernment, to work with other countries to decide on public health needs, and to address potential public emergencies. Report to the world and be accountable to the general public about health events. The 194 World Health Organization member states have now signed the agreement to work together on global health security issues. It should be noted that one third of the world's countries have fulfilled the obligations of this agreement. In order to implement these rules, a voluntary and comprehensive process called Joint External Evaluation (JEE) has been established, which identifies gaps in countries 'health systems, increases countries' response and preparedness opportunities, and provides members and donors with access to Putting resources into countries works. Hundreds of JEE teams in the form of the World Health Organization are working with UN members to implement the provisions of the IHR (CDC, 19 August 2019, cdc.gov). Obviously, the difficulty of the mission assigned to these regulations, regardless of the need to implement Minimal interference in the internal affairs of states remains ineffective; therefore, within the framework of Article 3 of the Regulations, the implementation of all regulations in the light of full respect for inherent dignity, human rights and fundamental freedoms on the one hand, and the protection of public health on the other; It is up to governments to fulfill their organizational obligations.

Pursuant to Article 12 of the Regulations, the DirectorGeneral of the World Health Organization has the power to declare a situation which immediately endangers public health an "international concern". Of course, this is only subjected to the opinion of the Emergency Committee established in Article 48 of these Regulations. According to Article 1 of the Regulations, any unusual health event which, through the global outbreak of a disease, poses a threat to the public health of other countries, and which potentially requires a response based on the cooperation of other countries, is considered an international health emergency. However, it is possible to determine whether a situation has reached an emergency level based on findings based on the prevalence of the disease, and this in itself is a function of the extent to which accurate information of the prevalence of the disease can be obtained. Because this information is provided through governments and, in other words, the competent national authorities, and made available to the organization, the issue of accuracy and precision in the information is crucial in determining any situation. According to Article 7 of the Regulations, countries are required to provide all relevant public health information to a competent international authority. Paragraph 1 of Article 9 of these Regulations also states that the World Health Organization, in determining the nature of any situation, shall take into account the reports prepared by authorities other than the competent national authorities. However, according to paragraph 1 of Article 10 of these Regulations, the authority to approve reports submitted by non-governmental organizations is the organization itself. The decision to publish the status of states that are not willing to cooperate in any case is also based on paragraph 4 of Article 10 with the organization itself, although in such cases the organization will continue to encourage the relevant country to accept the offer of cooperation (Shahbazi, 8 Hamal 1399, tisri.org ).

Pursuant to Article 15 of the Regulations, the organization, after determining the state of emergency, issues recommendations, which are generally based on the adoption of recommendations to reduce travel or impose trade restrictions as much as possible. Non-compliance with the decisions of the Organization by member countries shall be reported by the Organization to other States. It can also give instructions to the people of the world. For example, it told the people of the world not to travel to prevent the corona virus. .

Other international organizations, in consultation with and under the auspices of the World Health Organization, have taken a number of steps that can even be seen in the UN Security Council. After repeated warnings from the World Health Organization and the Secretary-General of the United Nations, the Security Council finally put the issue of the corona on its agenda on 5/25/2020 (Al-Arabiya Farsi News Agency, 24 May 2020).

Thus, liberals have shown that the rules and regulations of international organizations, especially the World Health Organization, have influenced the actions of various countries around the world. These range from public health education to creating quarantine conditions and even encouraging the development of coronavirus vaccines. However, the organization does not have enough executive power to force governments to take such action. Even this organization does not have the ability to reflect and list the actions of different governments (how each government operates) and only the necessary information in this regard can be obtained through news agencies. It has called on governments to take action in the General Assembly. Finally, the organization has the role of encouraging and setting an example for countries, for example, by proposing that countries learn from China how to control the disease.

Therefore, according to this approach, governments have limited their scope of action in terms of their responsibilities to their people, as well as their commitments in the international arena and the formation of international organizations, and coronary heart disease is the basis for governments to abide by the rules. The commonalities and arrangements created by international institutions are more structured.

\section{Conclusion}

There is widespread disagreement over the impact of the corona on international politics, most notably between realists and liberals. Emphasizing their initial assumptions, 
realists believe that the corona has increased citizens' sense of belonging to their respective governments and reduced their sense of belonging to the international community. According to their premises, it is these governments that have taken the necessary and immediate measures to fight the coronavirus. Powerful countries will also emerge from this successful test. International institutions have failed to help countries in conflict with the Corona (such as the European Union in helping Italy).

Liberals, on the other hand, who believe in universal human rights, emphasize the interdependence of nations and international cooperation. Although realists criticize the approach that the Corona virus has become widespread due to the phenomenon of globalization and high international communication, liberals conclude from the current crisis that although governments have an important role to play in controlling it, they have resorted to global measures to combat it. It is necessary with this virus. Extensive cooperation between countries is still needed to overcome this crisis. Communities are affected by events in other countries. They are working together to find a solution to this crisis, and international institutions have played a major role in tackling the disease.

Looking at the progress of the right to health in domestic and international texts and the commitment of governments to ensure the health of our citizens, we realize that not only the right to health has historically followed the standards of human rights, but the right to health is a fundamental human right, Which is recognized in the domestic and international human rights system.

Thus, international law solutions about the events such as the corona that threaten public health can be seen in the almost common policy adopted by most countries and the actions of international organizations (especially the World Health Organization). Where the socio-biology of the international community is intertwined, there is no difference between developing and developing governments. As much as the corona can be a threat to the citizens of developing countries, it can seriously endanger the health and right to life of the people of developed countries. In such situations, adherence to the moral obligations of states in the international community is more evident than their legal obligations. Transparency in the provision of scientific and documented statistics on the prevalence of the disease not only provides a basis for citizens' trust in the government, but also leads to respect for the international community and public health worldwide.

As a result, although realists are considered by governments to be the most important actors in counteracting the coronation, and these governments act in the national interest, the impact of international law rules such as human rights and especially the right to health in domestic systems must be considered. Today, governments have become more focused on their borders and imposed restrictions on trade and commerce to counter the corona, but from a liberal point of view, these measures are in themselves international cooperation. This cooperation can be considered as a kind of negative rather than positive cooperation. Only through the attention of governments to the highest interests of the international community, respect for the right to life enshrined in the Universal Declaration of Human Rights and other human rights instruments, respect for the principle of good faith in international relations as a fundamental component of many contractual and non-contractual obligations Humanity in the system of the international system, increasing international cooperation, respecting the principle of information in times of need, applying the principle of caution and proper care in all biological matters can be the "essence of health", this irreplaceable divine promise for human beings.

\section{References}

[1] Universal Declaration of Human Rights (December 10, 1948) adopted by the United Nations General Assembly.

[2] ArameshShahbazi (1/8/1399), Legal Analysis of Coronavirus Outbreak in the Field of International Health Regulations, Abrar Contemporary International Research and Research Institute, Tehran, available at http://tisri.org/?id=gblaw0j8

[3] Aghababayan, Hamidreza (March 15, 2017) Corona epidemic from the perspective of rights and rights to citizens' health, available at https://www.khabaronline.ir/news/1362561

[4] Barkin, Samuel J. (2014) International Organizations, Theories and Institutions, translated by Mostafa Entezar Al-Mahdi and AbdolmajidSeifi, Tehran: Kavir.

[5] Barchil, Scott et al. (2013) Theories of International Relations, translated by SajjadHeidarifard, Tehran: University Jihad Organization.

[6] Jackson, Robert and Gork Sorenson (2012) An Introduction to International Relations, translated by Mehdi Zakerian, Ahmad Taghizadeh and Hassan Saeed Kolahy, Tehran: Mizan.

[7] Hosseini, SeyedHadi (2015) The Subordinate Responsibility of the Government in Compensating for Irreparable Damages to Citizens, Quarterly Journal of Iranian and International Comparative Law Research, Volume 8, Number 28, pp. 123-166.

[8] Al-Arabiya Farsi News Agency, 4/26/2020, the Security Council enters the phase of countering the Corona after a period of silence, available at https://farsi.alarabiya.net/en/2020/04/26

[9] Rahimi, Gholamreza (2010) World Health Organization, Journal of the Paramedical School of the Army of the Islamic Republic of Iran, Fifth Year, No. 1, pp. 53-56.

[10] Constitution of Afghanistan (2003), published in the official newspaper of Afghanistan, No. 818.

[11] Civil Law (1355), published in the official newspaper of Afghanistan, p. 353.

[12] Mustafa Mohammadyar (1/25/1399) The Age of Coronation and Non-Contractual Civil Liability of the Government towards Citizens, our Afghanistan newspaper, available at http://www.dailyafghanistan.com/opinion_detail.php?p ost_id=152743 